nancies. Report of two cases and review of the literature. Am ₹ Surg Pathol 1985;9:23-30.

7 Nichols $\mathrm{CR}$ Hoffman $\mathrm{R}$ - Winhorn $\mathrm{LH}$, Wiliams Wheeler LA, Garnick MB. Hematologic malignancies associated with primary mediastinal germ cell tumors. Ann

8 Chaganti RS, Ladanyi M, Samaniego F, Offit K, Reuter $\mathrm{VE}$, Jhanwar SC, et al. Leukemic differentiation of a mediastinal germ cell tumor. Genes Chromosom Cancer 1989;1:83-7.

9 Nichols CR, Roth BJ, Heerema N, Griep J, Tricot G. Hematologic neoplasia associated with primary mediastinal germ-cell tumors. $N$ Engl $f$ Med 1990;322: 1425-9.

10 Mandel M, Toren A, Kende G, Neuman Y, Kenet G,
Rechavi G. Familial clustering of malignant germ cell tumors and Langerhans' histiocytosis. Cancer 1994;73. tumors

11 Rabkin MS, Wittwer CT, Kjeldsberg CR, Piepkorn MW. Flow-cytometric DNA content of histiocytosis X (Langerhans cell histiocytosis). Am f Pathol 1988;131:283-9. 12 Van Heerde $P$, Maarten Egeler $R$. The cytology of Langerhans cell histiocytosis (histiocytosis X). Cytopathology 1991;2:149-58.

13 Gordon S. Defense mechanisms. The mononuclear phagocyte system. In: McGee JO'D, Isaacson PG, Wright NA eds. Oxford textbook of pathology. 1st edn. Oxford: Oxford University Press, 1992:236-58.

14 Ladanyi M, Roy I. Mediastinal germ cell tumors and histiocytosis. Hum Pathol 1988;19:586-90.

\title{
Papillary mucinous adenoma arising in adenomyomatous hyperplasia of the gall bladder
}

\author{
G Y Lauwers, S J Wahl, G V Scott, S J DeRoux
}

University of Florida College of Medicine, Department of Pathology and Laboratory Medicine, Gainesville, Florida, USA G Y Lauwers G V Scott

Lenox Hill Hospital, Department of Pathology, New York, New York, USA $S$ J Wahl $S$ J DeRoux

Correspondence to: Dr G Y Lauwers, Department of Pathology and Laboratory Medicine University of Florida College of Medicine,

P.O. Box 100275

Gainesville,

Florida 32610, USA.

Accepted for publication 21 February 1995

\begin{abstract}
A case of papillary mucinous adenoma arising in adenomyomatous hyperplasia (AMH) of the gall bladder is reported. The lesion was unsuspected and discovered by routine palpation of the gall bladder during laparotomy. The adenoma developed within fundal AMH and showed cytological atypia. This case illustrates that neoplastic proliferation is indeed possible in AMH and challenges the classical opinion that AMH is devoid of neoplastic potential. (f Clin Pathol 1995;48:965-967)
\end{abstract}

Keywords: Gall bladder, cancer, adenomyomatous hyperplasia, adenomyomatosis, mucinous adenoma.

Adenomyomatous hyperplasia (AMH), also known as adenomyomatosis, is the most frequently diagnosed pseudotumour of the gall bladder. ${ }^{1}$ Although classically considered to be a hyperplastic lesion, recent reports showed not only a causative relation between $\mathrm{AMH}$ and gall bladder carcinoma, but also actual neoplastic degeneration arising in $\mathrm{AMH} .^{2-8}$ Here, we report a unique case of adenomatous changes and evidence of neoplastic potential in $\mathrm{AMH}$.

\section{Case report}

An 86 year old woman was admitted for surgery following a diagnosis of adenocarcinoma of the left colon. A preoperative workup showed no evidence of metastatic tumour and a left hemicolectomy was performed. At surgery, palpation of the gall bladder revealed a small soft mass at the tip of the fundus and a cholecystectomy was performed. The postoperative course was uneventful and the patient is alive and well 17 months after surgery.

\section{Methods}

Sections of the gall bladder were fixed in $10 \%$ buffered formalin and embedded in paraffin wax. Paraffin wax sections $4 \mu \mathrm{m}$ thick were stained with haematoxylin phloxine saffron. Histochemical stains including periodic acid Schiff (PAS), with and without diastase pretreatment, mucicarmine, and alcian blue were applied to the sections. Sections were also stained immunohistochemically with chromogranin (Boehringer Mannheim, Indianapolis, Indiana, USA) monoclonal antibodies using the avidin-biotin peroxidase technique, as described previously. ${ }^{9}$

\section{Results}

PATHOLOGICAL FINDINGS

On gross examination, the fundus of the acalculous gall bladder showed a dome shaped, cystic lesion measuring $2 \times 1.3 \times 1 \mathrm{~cm}$. Microscopically, the gall bladder mucosa showed normal luminal folds lined by a single layer of columnar epithelium. The stroma was slightly fibrotic and contained lymphocytes in small clusters. AMH was identified within the wall of the fundus as the typical multiple anastomosing, epithelium lined extrusions extending between bundles of hyperplastic smooth muscle. Foveolar type mucinous metaplasia of the hyperplastic epithelium was also present. A large cyst measuring $11 \times 5 \mathrm{~mm}$ was observed in continuity with AMH. Its lining was composed of tall mucinous cells with focal formation of papillae (figs 1 and 2). A large villous polypoid lesion formed of anastomosing fronds protruded into the cystic space. The fibrovascular stroma of the papillae was infiltrated by lymphocytes and plasma cells. Most of the fronds were lined by a single layer of benign mucus cells, although focal cellular tufting and nuclear atypia were present. 


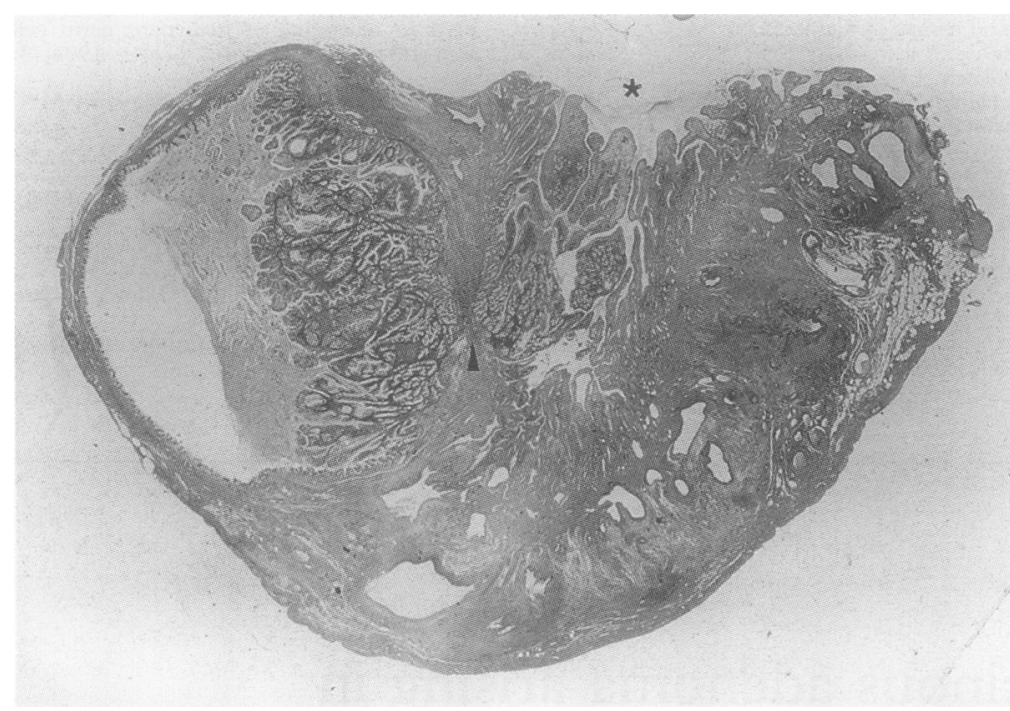

Figure 1 Low power view of the fundus of the gall bladder. Prominent AMH extends from the luminal surface (star) into the thickened wall. The AMH associated papillary adenoma can also be seen (arrow head).

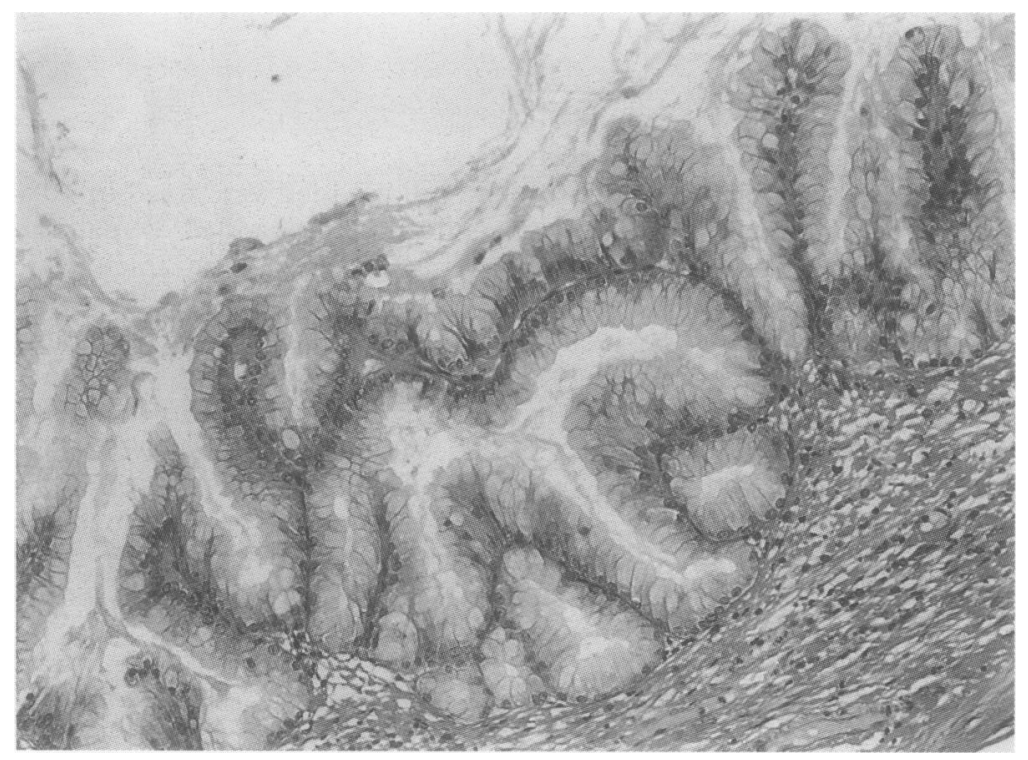

Figure 2 Lining of the cyst composed of an inconspicuous mucinous epithelium forming small papillary fronds. to the surface epithelium of the gall bladder, the foveolar type metaplastic epithelium of the $\mathrm{AMH}$ and the adenoma lacked acid mucins but were positive for neutral mucin. The histological and histochemical similarity support the conclusion that the papillary mucinous adenoma arose from the AMH. To the best of our knowledge, the present case is the first detailed description of such neoplastic change arising within $\mathrm{AMH}$. In 1982, Von Matting et $a l^{10}$ described a so-called "benign papillary cystadenoma of the gall bladder fundus", suggesting a similar lesion, but their report did not contain a precise microscopic description. $\mathrm{AMH}$, regarded as a hyperplastic lesion, combines excessive surface epithelial proliferation with extrusion of the mucosa through a thickened muscular wall. ${ }^{11}$ This acquired process can be diffuse, segmental, or localised with a propensity for the fundus. ${ }^{1}$ Its frequency has been reported to vary between 2 and $25 \%$ in both surgical and radiological retrospective studies. ${ }^{1213}$ More commonly recognised in women, its incidence increases with age. ${ }^{14} \mathrm{Al}$ though most lesions are asymptomatic, nonspecific cholecystitis-like symptoms have been reported. ${ }^{1415}$ Cyst formation secondary to inflammation, fibrosis, and inspissated bile has also been described. ${ }^{14}{ }^{15}$ Abscess formation has been the most frequently reported complication. ${ }^{16}$

The association between AMH and gall bladder cancer is unclear. ${ }^{17}$ Although regarded classically as a benign process, recent publications have challenged this opinion. Ootani et $a l^{4}$ redefined the association between $\mathrm{AMH}$ and gall bladder cancer. In their series $11.4 \%$ of gall bladder cancers developed in the fundal compartment, distal to the stricture induced by AMH. They suggested that segmental AMH was a causative factor in gall bladder cancer, but indicated that this relation was not true for diffuse or fundal $\mathrm{AMH}$. Of more interest in the light of the case reported here are the eight cases of gall bladder cancer which developed directly in AMH. ${ }^{235-8}$ The following are of particular relevance: four of the eight gall bladder cancers developed in localised AMH of the fundus ${ }^{2568}$; mucinous metaplasia was present in two of these four cases ${ }^{26}$; and in one case the carcinoma arose from a papillary adenoma similar to the case presented in this report. ${ }^{6}$

The case presented here, supported by the recent reports of gall bladder cancer arising in $\mathrm{AMH}$, suggests that $\mathrm{AMH}$ may have neoplastic potential. In some cases at least an adenoma could be one of the intermediate steps in the carcinogenic sequence. The possibility that mucinous metaplasia in $\mathrm{AMH}$ is indicative of a predisposition to neoplasia requires investigation. That the histological features of our case are reminiscent of the mucinous cystadenoma of the appendix is of particular interest.

The clinical significance of our finding is limited at present. $\mathrm{AMH}$ is a frequent finding during surgery and has an excessively low malignant potential (if any greater than normal epithelium). None the less, awareness of the possibility of malignant degeneration might be
A case of low grade papillary mucinous adenoma arising in AMH, showing foveolar type mucinous metaplasia, is reported. In contrast 
clinically important. As AMH can be easily recognised on ultrasonography, ${ }^{18}$ any unusual modifications of the sonographic structure or development of a mass necessitate rigorous follow up. Early recognition of degenerative change is vital as early gall bladder cancer has a distinctly better prognosis than advanced disease. ${ }^{17}$

1 Christensen AH, Ishak KG. Benign tumors and pseudotumors of the gallbladder. Report of 180 cases. Arch Pathol tumors of the gallb

2 Aldridge MC, Gruffaz F, Castaing D, Bismuth H. Adenomyomatosis of the gallbladder. A premalignant lesion? Surgery 1991;109:107-10.

3 Arianoff AA, Vielle G, Dewulf E. Le cancer de la vésicule. A propos de 49 cas cholecystectomisés. Acta Gastroenterol Belg 1973;36:310-31.

4 Ootani T, Shirai Y, Tsukada K, Muto T. Relationship between gallbladder carcinoma and the segmental type of adenomyomatosis of the gallbladder. Cancer 1992;69: 2647-52.

5 Kawarada Y, Sanda M, Mizumoto R, Yatani R. Early carcinoma of the gallbladder, noninvasive carcinoma originating in the Rokitanshy-Aschoff sinus: a case report. ginating in the Rokitanshy-Ascho

6 Katoh T, Nakai T, Hayashi S, Satale T. Noninvasive carcinoma of the gallbladder arising in localized type ad- enomyomatosis. Am $\mathcal{f}$ Gastroenterol 1988;83:670-4.

7 Nakafuji H, Koike Y, Wakabayashi M, Furihata R, Maruyama $Y$, Ogata $H$. Three cases of early stage carcinoma of the gallbladder. Gastroenterol fpn 1981;16:134-40.

8 Paraf F, Molas G, Potet F. Diverticulose intramurale et cancer de la vésicle biliaire. Gastroenterol Clin Biol 1987 11:825-7.

9 Cartun RW, Pedersey CA. An immunocytochemical technique offering increased sensitivity and lower cost with streptavidin-horseradish peroxidase conjugate. $\mathcal{f}$ Histotechnol 1980;12:273-7.

10 Von Matting H, Muller W, Liebe G, Schulz HG. Gutartiges papillares kystadenom der gallenblase mit inkompletter temporaremcholestase und begleitpankreatitis. Zentralbl Chir 1982;107:236-9.

11 Weedon D (ed). Adenomyomatosis. In: Pathology of the gall bladder. New York: Masson Publishing Inc, 1984:185-94.

12 Jutras JA. Hyperplastic cholecystoses. Am $\mathcal{F}$ Roentgenol 1960; 83:795-827.

13 Meguid MM, Aun F, Bradford ML. Adenomyomatosis of the gallbladder. Am $\mathcal{f}$ Surg 1984;147:260-2.

14 Ram MD, Midha D. Adenomyomatosis of the gallbladder. Surgery 1975;78:224-9.

15 Fotopoulos JP, Crampton AR. Adenomyomatosis of the gallbladder. Med Clin North Am 1964;48:9-36.

16 Shepard VD, Walters W, Dockerty MB. Benign neoplasms of the gallbladder. Arch Surg 1942;45:1-18.

17 Aldridge MC, Bismuth H. Gallbladder cancer: the polypcancer sequence. $B r \mathcal{F}$ Surg 1990;77:363-4.

18 Rice J, Sauerbarei EE, Semogas P, Cooperberg PL Burhenne HJ. Sonographic appearance of adenomyomatosis of the gallbladder. $f$ Clin Ultrasound 1981;9: 336-7.

\title{
Induction of interleukin-8 secretion from gastric epithelial cells by a $\operatorname{cag} A$ negative isogenic mutant of Helicobacter pylori
}

\author{
J E Crabtree, Z Xiang, I J D Lindley, D S Tompkins, R Rappuoli, A Covacci
}

Division of Medicine, St James's University Hospital, Leeds LS9 7TF

J E Crabtree

Public Health

Laboratory, Leeds LS15 7TR

D S Tompkins

Sandoz Research Institute,

Vienna, Austria

I J D Lindley

Immunobiological

Research Institute

Siena (IRIS),

Siena, Italy

Z Xiang

R Rappuoli

A Covacci

Correspondence to:

Dr J E Crabtree.

Accepted for publication

30 March 1995

\begin{abstract}
The ability of Helicobacter pylori strains to induce interleukin-8 (IL-8) gene expression and protein secretion from gastric epithelial cell lines in vitro is variable. This cellular response is associated with bacterial expression of the CagA protein present in type $\mathrm{I} H$ pylori strains. To determine the role of CagA in this host cell response, an isogenic $\operatorname{cag} A$ negative mutant, N6.XA3, was constructed. The $\operatorname{cag} A$ negative isogenic mutant and the wild-type parental cagA positive strain, N6, were cocultured with AGS, ST-42 and KATO-3 gastric epithelial cell lines and secreted interleukin-8 assayed by enzyme linked immunosorbent assay. In all three cell lines there was no significant difference in the IL-8 secretion induced by the $\operatorname{cag} A$ negative isogenic mutant, N6.XA3, and the wild-type parent strain, N6. These studies show that CagA is not the inducer of IL-8 secretion from gastric epithelial cells. As all wild-type CagA positive strains studied to date induce IL-8, the bacterial factor(s) inducing this inflammatory response is
\end{abstract}

closely associated with the expression of CagA.

(f Clin Pathol 1995;48:967-969)

Keywords: Interleukin-8, Helicobacter pylori, CagA, epithelial cells, gastritis.

The CagA surface protein of Helicobacter pylori is highly immunogenic and is expressed in about 60 to $70 \%$ of $H$ pylori strains. ${ }^{1-3}$ Mucosal IgA antibody recognition of this protein has been linked with peptic ulcer disease and the activity of gastritis ${ }^{4}$ and systemic IgG responses to CagA are also elevated in ulceration. ${ }^{15}$ Strains of $H$ pylori which have the gene coding for CagA and express this immunogenic protein usually coexpress the vacuolating cytotoxin (VacA). ${ }^{3}$ Strains with this genotype/phenotype have recently been classified as type I bacteria. ${ }^{3}$ Type II strains lack the $\operatorname{cag} A$ gene and express neither the CagA protein nor the VacA protein. ${ }^{3}$ While the VacA protein is thought to be an important mediator of gastric mucosal damage, this protein does not elicit gastric inflammatory cell infiltration in animal models. ${ }^{6}$ 